\title{
THE IMPACT OF R\&D EXPENDITURE ON PRODUCTIVITY IN THE MANUFACTURING INDUSTRY IN POLAND
}

\author{
Elżbieta Roszko-Wójtowicz
}

University of Lodz, Lodz, Poland

e-mail: elzbieta.roszko@uni.lodz.pl

ORCID: 0000-0001-9337-7218

\section{Maria M. Grzelak}

University of Lodz, Lodz, Poland

e-mail: maria.grzelak@uni.lodz.pl

ORCID: 0000-0003-4353-9893

\section{Iwona Laskowska}

University of Lodz, Lodz, Poland

e-mail: iwona.laskowska@uni.lodz.pl

ORCID: 0000-0002-1657-5541

(C) 2019 Elżbieta Roszko-Wójtowicz, Maria M. Grzelak, Iwona Laskowska

This is an open access article distributed under the Creative Commons Attribution-NonCommercial-NoDerivs license (http://creativecommons.org/licenses/by-nc-nd/3.0/)

DOI: 10.15611/eada.2019.4.08

JEL Classification: C23, E23, O30

\begin{abstract}
EU strategy documents, including the Europe 2020 Strategy, emphasise the priority role of industry in the growth of EU economies. The aim of the presented research is to measure and assess the impact of expenditure on research and development (R\&D) activities on the competitiveness of manufacturing divisions in Poland. Labour productivity, expressed as (1) a quotient of gross value added and employment, and (2) a quotient of sold production and employment in the analysed manufacturing divisions, was adopted as the measure of competitiveness. The empirical part of the paper is based on data published by the Central Statistical Office. The analysis covers the period 2009-2017 and provides a contribution to determining the role and importance of research and development as well as innovative activities in shaping competitive advantages of manufacturing enterprises. The obtained results for panel models confirm that $\mathrm{R} \& \mathrm{D}$ expenditure is a secondary factor in changes occurring in the Polish manufacturing industry.
\end{abstract}

Keywords: R\&D expenditure, competitiveness, manufacturing, static panel models, dynamic panel models. 


\section{Introduction}

In most EU countries, despite the growing importance of the services sector, industry continues to play a key role in the development and functioning of national economies. In the years preceding the global financial crisis, which began in 2008 in the USA, the prevailing belief was that economic development could only be achieved through the development of the services sector and the financial sector, while industry was considered a declining sector.

However, the financial crisis, its consequences and the relatively poor performance of the economies of the EU countries have changed the perception of industry, which has again become recognised as the driving force of sustainable economic and social development. In the literature there is a renaissance of the views expressed by the famous economist J. Schumpeter, for whom industry was the heart of capitalism, the place from which the impulses for the rest of the economy emerged, including services which generated a greater share of GDP but at the same time preyed on the real product created by the 'hard' economy [Ślusarczyk 2016, p. 8].

The importance of industry stems also from the fact that it plays important economic functions (processing raw materials and semi-finished products into finished products, co-creating domestic product, stimulating regional economic development, and the development of other sectors of the economy), social functions (creating jobs and sources of livelihood, shaping the structure of education) and spatial functions (transformation of the natural environment, acceleration of urbanisation processes).

The aim of the presented study is an attempt at the quantitative assessment of the impact of R\&D expenditure on the competitiveness of manufacturing divisions. As a measure of competitiveness, labour productivity, expressed as a quotient of gross value added and employment or as a quotient of sold production and employment in the analysed manufacturing divisions, was assumed.

The research is based on the analysis of the Cobb-Douglas production function extended to include the variable describing R\&D expenditure. In the study, taking into account the Polish Classification of Activities (PKD) 2007, manufacturing enterprises (Section C) were analysed at the two-digit level of aggregation, i.e. at the level of divisions of this section. The research proceedings were based on data published by the Central Statistical Office. The analysis covers the period 2009-2017 and provides a contribution to determining the role and importance of R\&D and innovative activity in shaping competitive advantages of manufacturing enterprises. 


\section{Literature review - selected issues}

The EU strategy documents [European Commission 2010a; European Commission 2010b; European Commission 2012] emphasise the priority role of industry in the growth of the EU economy and focus on the need to take measures to support longterm industrial development, and thus increase production and employment in this sector of the economy. The European Union in its reindustrialisation strategy assumes an increase in the share of industrial production in the creation of the EU GDP from 15.5\% in 2011 to 20\% in 2020 [European Commission 2014].

The conducted analysis of a number of economic indices, based on the results achieved by EU industry as well as by individual EU countries, confirms the need to apply the assumptions of the new industrial policy to increase the competitiveness of EU industry in the global economy.

The changes occurring in the global economy and progressive globalisation are increasingly affecting the functioning of industry in Poland as well. Its future remains strongly connected with its efficiency and competitiveness [Skrzypek 2012, p. 314]. These aspects are important for two reasons. First of all, new production systems can be developed provided the economic efficiency of operations is improved. Secondly, issues related to EU standards, environmental protection and limited natural resources require the consideration of these conditions in production systems. Meeting the challenges of efficiency and competitiveness is possible, among others, through the use of innovative methods of production, management and work organisation as well as the introduction of modern forms of distribution of goods.

The literature indicates that an important role in increasing efficiency and improving competitiveness is played by the activity of the R\&D sector as well as other sections and sectors of the economy that conduct research and implement innovations. The manifestations of this activity materialise in expenditure on innovation, R\&D and education as well as in the results of research in the form of patents and licences. In the endogenous theory of growth, it is assumed that technical progress stems primarily from innovations arising as a result of domestic and foreign R\&D activity and from the accumulation of human capital [Świeczewska 2007, p. 81].

According to M. Porter, the impact of innovative activities of manufacturing divisions on their competitiveness is reflected in changes in labour and capital productivity. A permanent increase in efficiency, defined by M. Porter as the generated value per unit of labour or capital, requires continuous progress in the economy, and thus the introduction of innovations. Increasing the efficiency of manufacturing divisions is possible by improving the quality of products, modifying them and improving the technology of their production. This means that innovations 
lead to changes in competitive advantages, which is ultimately reflected in changes in the productivity of production factors [Porter 1990; 2001].

It is worth noting that unequal outlays on innovative activity, including primarily $\mathrm{R} \& \mathrm{D}$, the level and structure of employment as well as organisation and cooperation in the field of innovative activity are the main reasons for the considerable diversity existing in the level of innovation in manufacturing divisions [Weresa 2006, pp. 202-203].

\section{Data on manufacturing in Poland}

The research described in the paper concerns time series and cross-sectional data, i.e. data that arose from combining the time series of observations derived from various objects into one set. In this case, objects, i.e. cross-sectional units, are manufacturing divisions in Poland divided in accordance with the applicable PKD (Polish Classification of Activities) classification. Such objects function in close connection with each other, although they remain separate units. It seems natural, therefore, that the behaviour of each object is influenced by individual factors, resulting only from its specificity, impacting the functioning of only this one object, as well as by other factors determining the activity of all objects in the same way and to the same extent. The presence of these 'common' factors justifies linking observations coming from different objects into one series and conducting econometric analyses based on thus combined data. Econometric models estimated on the basis of time series and crosssectional data samples, called panel data models, are usually oriented towards crosssectional analysis. Their task is to find differences between objects that are inseparably connected with factors specific to individual objects. Therefore, the heterogeneity of objects is an integral part or even the central issue of analysis (Greene 2000), while time effects are treated as step changes of state. These changes are usually modelled as effects specific to the time period in which they occurred and are not transferred to subsequent periods.

The paper uses data published by the Central Statistical Office. In particular, for the needs of the conducted analyses, data from the Statistical Yearbooks of Industry for the period 2010-2018 and from the Local Data Bank were obtained. Changes over time in the level of indices selected for the analysis covered the period 2009-2017. According to the Polish Classification of Activities, the initial database was prepared at the two-digit level of aggregation, i.e. for all 24 divisions of Section C Manufacturing. Due to data gaps, including those resulting from statistical secrecy, ultimately five divisions were excluded from the analyses, i.e. 11 - Manufacture of beverages, 12 - Manufacture of tobacco products, 14 - Manufacture of clothing, 15 Manufacture of leather and related products, and 19 - Manufacture and processing of coke and refined petroleum products. 
The role and importance of manufacturing in the Polish economy (2017) is evidenced, among others, by its share in: the creation of gross domestic product ( $22.8 \%$, compared to $23.5 \%$ in 2016 ), investment outlays (36.9\%, compared to $38.4 \%$ in 2016) and the gross value of fixed assets (32.6\%, compared to $32.5 \%$ in 2016). Employment in manufacturing in Poland remains at a stable level. Both in 2016 and in 2017, the share of employed persons in industry was $20.8 \%$ of the total number of persons employed in the country [GUS 2017, pp. 30-37; GUS 2018, pp. 30-31]. Nevertheless, individual data show that in 2017 almost 100,000 more people were employed in industry than in 2016 and nearly 300,000 more than in 2009 [GUS 2018, p. 29]. An in-depth analysis of data from the last few years confirms that manufacturing in Poland is an important element of the national economy, which is manifested by newly created jobs and the increasing gross value of fixed assets. In comparison with 2010, the number of people working in industry increased by almost $5.5 \%$ and the value of fixed assets grew by $39 \%$. The production of the manufacturing sector in Poland is very diverse. Among the main commodities produced by the Polish manufacturing industry in 2017, the following can be mentioned: sugar (2215 thousand tons), timber (4990 decametres), mineral or chemical fertilizers (3222 thousand items, including nitrogen - 2058 thousand items), plastics (3448 thousand tons), radio receivers (2285 thousand items) and television sets (21303 thousand items), as well as washing machines (3222 thousand items), and vacuum cleaners (6712 thousand items). It is worth adding that the most spectacular increase in production volume was recorded in the case of radio receivers whose production increased by 2267.3 thousand units in 2017 in comparison to 2009. When analysing manufacturing it is worth examining its potential to compete internationally, which seems to be crucial in the context of the stated aim of the paper which is the quantitative assessment of the relationship between expenditure on innovative activity and gross value added in manufacturing enterprises. In terms of value, the group of Poland's three most important export goods comprises parts and accessories for motor vehicles (PLN 44792.1 million), plastics (PLN 30788.1 million) and passenger cars (PLN 30269.6 million) [GUS 2017, pp. 260-262]. Poland, as a member of the EU structures, is one of the eight countries in which exports of goods to other countries in 2017 were over EUR 150 billion. In addition, the value of exports from Poland to trade partners from the EU countries in the period 2003-2017 was characterised by an average annual increase of $10.7 \%$ [EUROSTAT, Statistics explained 2019].

Analysing CSO statistical data (see Figure 1), it can be stated that in the period 2009-2017, output, sold production, gross value added and gross value of fixed assets were characterised by a clear upward trend. Despite the growth recorded at the level of $30.1 \%$ in 2017 compared to the baseline year, in the last two years, i.e. 2016-2017, 


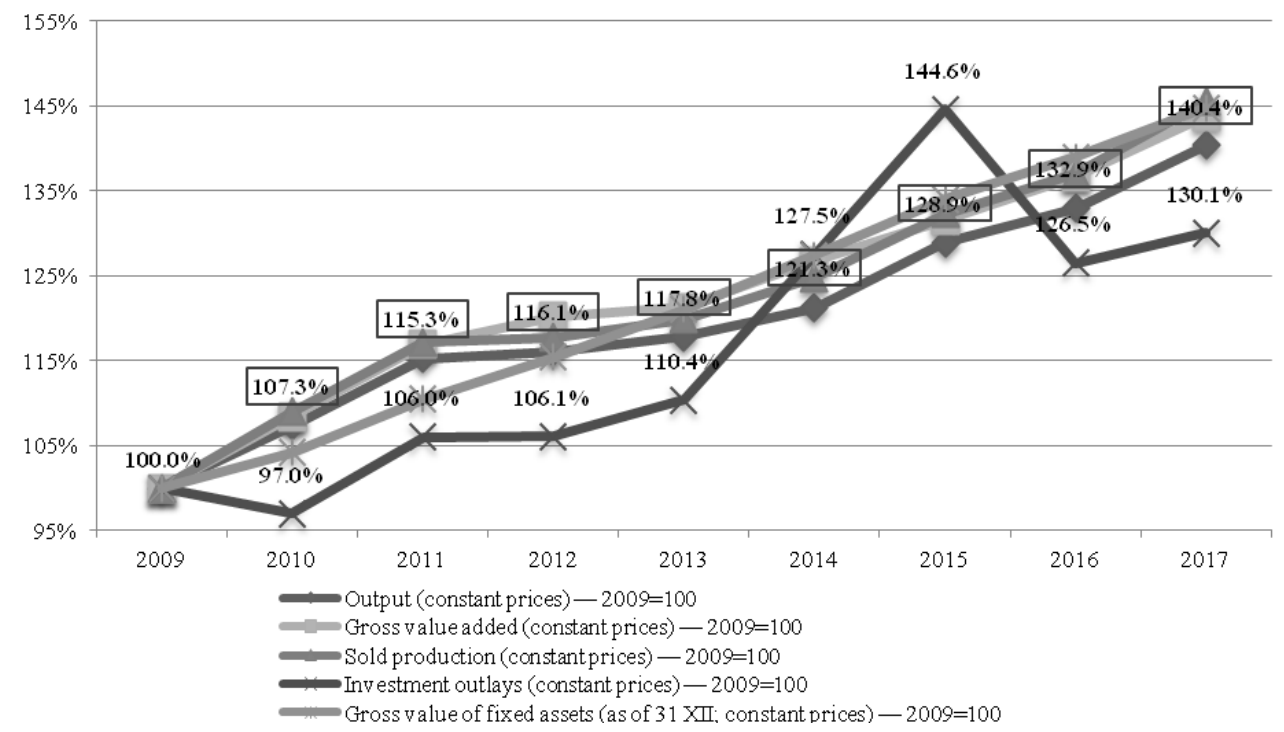

Fig. 1. The dynamics of selected indices describing the development of manufacturing in Poland in the period 2009-2017

Source: own elaboration based on [GUS 2018, pp. 24-25].

there was a drop in the level of investment outlays in industry in comparison with 2015. Nevertheless, referring to the entire analysed time horizon, the positive growth rate of the discussed indices confirms that manufacturing in Poland is developing and maintaining an important position in the economy.

The strength and prevalence of manufacturing, and especially its international potential, is demonstrated to a large extent by its capacity to generate and implement innovations. Hence the level of spending on R\&D is one of the indices analysed in this paper. Against the background of the entire EU, the situation of Poland is not the most favourable. In 2017, R\&D expenditure in the EU increased to $2.07 \%$ of GDP, while in Poland it amounted to only $1.03 \%$. Despite the positive changes observed, i.e. an increase in $R \& D$ intensity followed by higher R\&D expenditure, Poland is still at the bottom of the ranking of the EU countries [EUROSTAT, News release 2019]. The conducted analysis of research and development expenditure by sector has revealed that on average $66 \%$ of $R \& D$ expenditure in the $\mathrm{EU}$ is incurred by business enterprises. The situation is similar in Poland, where the business enterprises sector incurred $64 \%$ of total R\&D expenditure disbursed in 2017. It is worth analysing the research and development expenditure situation in relation to the level of innovativeness of individual EU member states. Generally, in countries such as: Denmark, Sweden, Finland, and Germany, in which a high level of innovation 
performance is observed (e.g. on the basis of their position in the international Summary Innovation Index ranking), the business enterprise sector has a dominant share in R\&D expenditure. At the same time the shares of the other two sectors, government and higher education, are relatively evenly distributed, with a more prevalent role of higher education. However, in the case of countries whose position in innovation rankings is worse (e.g. Romania, Slovakia, Bulgaria and Croatia), a relatively high share of the government sector in the total expenditure on research and development activity is observed. The only exception here is Luxembourg, in which the share of the business enterprises sector in $R \& D$ spending has declined significantly in favour of an increase in the share of the government sector as well as higher education.

The data used in the paper include six diagnostic variables (see Table 1), of which five were presented in terms of value in constant prices from 2009. The price index of investment outlays, the price index of GDP and the price index of sold production of individual manufacturing divisions were used as the deflator.

Table 1. The list of diagnostic variables along with related deflators

\begin{tabular}{|c|l|l|}
\hline Symbol & \multicolumn{1}{|c|}{ Name of variable } & \multicolumn{1}{c|}{ Name of deflator } \\
\hline $\mathrm{X}_{1}$ & $\begin{array}{l}\text { Expenditure on innovative activity in the field of } \\
\text { product and process innovations in industry (in PLN } \\
\text { million) }\end{array}$ & Price index of investment outlays \\
\hline $\mathrm{X}_{2}$ & $\begin{array}{l}\text { Expenditure (internal and external) on research and } \\
\text { development (in PLN million) }\end{array}$ & Price index of investment outlays \\
\hline $\mathrm{X}_{3}$ & Average employment (in thousands of people) & $\mathrm{n} / \mathrm{a}$ \\
\hline $\mathrm{X}_{4}$ & Gross value added (in PLN million) & Price index of GDP \\
\hline $\mathrm{X}_{5}$ & Sold production (in PLN million) & $\begin{array}{l}\text { Price index of sold production } \\
\text { of manufacturing divisions }\end{array}$ \\
\hline $\mathrm{X}_{6}$ & Investment outlays (in PLN million) & Price index of investment outlays \\
\hline
\end{tabular}

Source: own elaboration.

\section{Research methodology}

Due to the panel structure in which the basic period is the calendar year and the objects are manufacturing divisions, the research uses appropriate models for this type of data in the static and dynamic version. This type of data allows us to take into account the heterogeneity of manufacturing divisions. The most general model based on cross-sectional data can be written in the following form:

$$
y_{i t}=\alpha_{i}+\mathbf{x}_{\mathrm{it}}^{\mathrm{T}} \boldsymbol{\beta}+\varepsilon_{i t},
$$

where: index $I=1, \ldots, N$ denotes the object, $t=1, \ldots, T$ - the time period, while $\mathbf{x}$ is the vector of observations of explanatory variables of $K$ coordinates. The use of such models requires that the following assumptions are met: 
the expected value $E\left[\varepsilon_{i t}\right]=0$ and the variance of the random component is constant, i.e. $E\left[\varepsilon_{i t}^{2}\right]=\sigma_{e}^{2}$.

The presented research used the two most popular approaches that allow us to take into account the heterogeneity of the studied objects: the fixed effects model (FEM) and the random effects model (REM). In the fixed effects model, the absolute term $\alpha_{i}$ is an object-specific effect, with the same distribution in groups and time, with a mean of 0 and a variance equal to $\sigma_{\alpha}^{2}$. Testing the significance of variation of individual effects in the FEM comes down to the verification of the hypothesis: $H_{0}: \alpha_{1}=\alpha_{2} \ldots=\alpha_{n}=\alpha$, which means that effects specific to objects do not occur. For the verification of the null hypothesis, the statistic with the Fisher-Snedecor distribution with $N-1$ and $N(T-1)$ degrees of freedom [Dańska 1997, p. 52] is used:

In the random effects model, $\alpha_{i}$ are treated as random variables. It is assumed that they are independent of the random components $\varepsilon_{i t .}$ The random component in this case is written as follows: $u_{i t}=\alpha_{i}+\varepsilon_{i t . .} \alpha_{i}$ contains all the unobservable factors specific to a given object [Maddala 2006]. In the case of random effects models, to test the significance of the variation of individual effects, the Breusch-Pagan test based on the Lagrange multiplier is used: $H_{0}: \sigma_{\alpha i}^{2}=0$ against the alternative hypothesis $H_{1}: \sigma_{\alpha i}^{2} \neq 0$. The choice between the FEM and REM is made using the Hausman test [Dańska 1997, p. 53]. The null hypothesis of the test assumes that individual effects are independent of explanatory variables and both estimators are unbiased. In this situation, the estimator for the random effects model (REM) is considered more effective.

Dynamic panel models allow us to take into account the persistence of economic phenomena. In general, the dynamic panel model can be represented as follows:

$$
y_{i t}=\gamma y_{i, t-1}+\boldsymbol{x}_{i t}^{T} \boldsymbol{\beta}+u_{i t}=\gamma y_{i, t-1}+\boldsymbol{x}_{i t}^{T} \boldsymbol{\beta}+\alpha_{i}+\varepsilon_{i t} ; i=1, \ldots, N, t=1, \ldots, T,
$$

where: $\gamma$-autoregressive coefficient.

For the estimation of dynamic panel models, different methods should be used from those used for static models. The methodology proposed in the literature basically relies on one of three methods: the Instrumental Variables Method (IVM) [Anderson, Hsiao 1981], the Generalised Method of Moments (GMM) [Arellano, Bond 1991] and the Maximum Likelihood Estimation (MLE) [Hsiao 2003]. The most commonly used in practice are the methods based on the Generalised Method of Moments (GMM), and especially the so-called first-differences GMM (FDGMM), proposed by Arellano and Bond in their work [1991], as well as the System GMM (SGMM), proposed by Blundell and Bond [1998]. Blundell and Bond's System GMM estimator (SGMM) uses additional restrictions of moments that are also appropriate when the FDGMM instruments are weak.

In the assessment of the GMM estimated model, particular attention is paid to two tests: the Arellano-Bond autocorrelation test and the Sargan-Hansen overidentifying restrictions test. The Arellano-Bond test examines the occurrence of second- 
order autocorrelation of the random component in the first differences model. With the standard assumption that the random components $e_{i t}$ do not show a correlation over time, in a correctly specified model it should be expected that increments of $\Delta e_{i t}$ will show a significant negative correlation of the first order and a lack of significant second-order correlation. The occurrence of the autocorrelation of the order higher than 1 in the first differences model would mean that the restrictions of moments are unfulfilled, hence the instruments used in the GMM estimation are not appropriate. The $H_{0}$ of the Arellano-Bond test indicates that such autocorrelation does not occur. The Sargan-Hansen test is used to test the correctness of overidentifying restrictions not used in the estimation process. According to the null hypothesis, the instruments used are appropriate in terms of a lack of their correlation with the random components of the first differences model.

\section{Research results}

Labour productivity can be measured in a variety of ways. It can be understood as production or gross value added per one employee or one hour of work [Freeman 2008].

In the presented research, labour productivity was presented in two variants:

1) as a quotient of gross value added and employment in manufacturing divisions;

2) as a quotient of sold production and employment in the analysed manufacturing divisions [Vieira, Vazquez-Rozas, Neira 2008; Welfe (ed.) 2002].

The use of new technologies and innovations in enterprises, apart from technical infrastructure, may be an important factor increasing employee productivity [Lokshin, Belderbos, Carree 2008]. In the analysis, this factor is reflected by expenditure on $\mathrm{R} \& \mathrm{D}$. The impact of $\mathrm{R} \& \mathrm{D}$ expenditure on labour productivity may be revealed with some lag. Finally, the panel model of labour productivity in manufacturing divisions, defined as gross value added (GVA) per employee in the static version, takes the form:

$$
\ln \left(\frac{G V A}{E m p l}\right)_{i t}=\alpha_{i}+\beta_{0}+\beta_{1} \ln \left(\frac{I n v O}{E m p l}\right)_{i t}+\beta_{2} \ln \left(\frac{R \& D}{E m p l}\right)_{i t}+\beta_{3} \ln \left(\frac{R \& D}{E m p l}\right)_{i, t-1},
$$

where: $\ln \left(\frac{G V A}{E m p l}\right)_{i t}$ - the natural logarithm of labour productivity understood as the relation of gross value added to the number of persons employed in the $i$-th manufacturing division in the year $t$.

$\ln \left(\frac{\operatorname{InvO}}{E m p l}\right)_{i t}$ - the natural logarithm of investment outlays at constant prices from 2009 in PLN million per employee (the CSO price index of investment outlays was used to adjust the data);

$\ln \left(\frac{R \& D}{E m p l}\right)_{i t}$ - the logarithm of $\mathrm{R} \& \mathrm{D}$ expenditure at constant prices from 2009 in PLN million per employee (the CSO price index of GDP was used to adjust the data); 
$\ln \left(\frac{R \& D}{E m p l}\right)_{i, t-1}-$ the natural logarithm of expenditure on $R \& D$ per employee in the time period $t-1$.

The appropriate model in the dynamic version has the form:

$$
\begin{gathered}
\ln \left(\frac{G V A}{E m p l}\right)_{i t}=\alpha_{i}+\beta_{0}+\gamma \ln \left(\frac{G V A}{E m p l}\right)_{i, t-1}+\beta_{1} \ln \left(\frac{\operatorname{InvO}}{E m p l}\right)_{i t}+ \\
\beta_{2} \ln \left(\frac{R \& D}{E m p l}\right)_{i t}+\beta_{3} \ln \left(\frac{R \& D}{E m p l}\right)_{i, t-1}+\varepsilon_{i t} .
\end{gathered}
$$

Table 3 presents the results of static and dynamic estimations of labour productivity models defined as gross value added per employee.

Table 2. Results of the estimation of parameters of labour productivity models in manufacturing

\begin{tabular}{|c|c|c|c|c|c|c|}
\hline \multirow{3}{*}{$\begin{array}{c}\text { Explanatory } \\
\text { variables and } \\
\text { selected statistics }\end{array}$} & \multicolumn{6}{|c|}{ Dependent variable $\ln \left(\frac{G V A}{E m p l}\right)_{i t}$} \\
\hline & \multicolumn{2}{|c|}{ FEM } & \multicolumn{2}{|c|}{ REM } & \multicolumn{2}{|c|}{ SGMM } \\
\hline & $\begin{array}{l}\text { parameter } \\
\text { estimation }\end{array}$ & $\begin{array}{c}t \\
(p \text {-value }) *\end{array}$ & $\begin{array}{l}\text { parameter } \\
\text { estimation }\end{array}$ & $\begin{array}{c}t \\
(p \text {-value })\end{array}$ & $\begin{array}{l}\text { parameter } \\
\text { estimation }\end{array}$ & $\begin{array}{c}t \\
(p \text {-value })\end{array}$ \\
\hline $\ln \left(\frac{G V A}{E m p l}\right)_{i, t-1}$ & 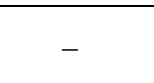 & & 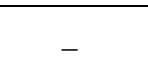 & & 0.707516 & $\begin{array}{r}24.25 \\
(0.000)\end{array}$ \\
\hline $\ln \left(\frac{\operatorname{InvO}}{E m p l}\right)_{i t}$ & 0.279 & $\begin{array}{r}6.363 \\
(0.000)\end{array}$ & 0.286 & $\begin{array}{r}7.285 \\
(3.23 e-013)\end{array}$ & 0.0929175 & $\begin{array}{r}8.084 \\
(0.000)\end{array}$ \\
\hline $\ln \left(\frac{R \& D}{E m p l}\right)_{i t}$ & 0.054 & $\begin{array}{r}3.338 \\
(0.001)\end{array}$ & 0.051 & $\begin{array}{r}3.347 \\
(0.001)\end{array}$ & 0.0166684 & $\begin{array}{r}2.557 \\
0.0105\end{array}$ \\
\hline $\ln \left(\frac{R \& D}{E m p l}\right)_{i, t-1}$ & 0.053 & $\begin{array}{r}3.070 \\
(0.002) \\
\end{array}$ & 0.050 & $\begin{array}{r}3.086 \\
(0.002)\end{array}$ & - & - \\
\hline Constant & 3.94976 & $\begin{array}{r}30.740 \\
(0.000) \\
\end{array}$ & 3.930 & $\begin{array}{r}31.79 \\
(0.000) \\
\end{array}$ & 1.143 & $\begin{array}{r}8.084 \\
(0.000)\end{array}$ \\
\hline R-squared & 0.92 & & & & & \\
\hline Within $R$-squared & 0.55 & & & & & \\
\hline $\begin{array}{l}\text { Assessment of the } \\
\text { significance of } \\
\text { individual effects } \\
\text { (value of test } \\
\text { statistics) }\end{array}$ & $\begin{aligned} F & =3 \\
(p & =0\end{aligned}$ & $\begin{array}{l}6.62 \\
000)\end{array}$ & $\begin{array}{r}\mathrm{LM}= \\
(\mathrm{p}=\end{array}$ & $\begin{array}{l}48.76 \\
.000)\end{array}$ & & \\
\hline Hausman test & & & $\begin{array}{r}\text { Chi-squar } \\
(0 .\end{array}$ & $\begin{array}{l}(3)=0.36 \\
48)\end{array}$ & & \\
\hline $\begin{array}{l}\text { Arellano-Bond } \\
\text { test (AR2) }\end{array}$ & & & & & $\begin{array}{l}z=1 \\
(0.0\end{array}$ & $\begin{array}{l}787 \\
38)\end{array}$ \\
\hline $\begin{array}{l}\text { Sargan-Hansen } \\
\text { test }\end{array}$ & & & & & $\begin{array}{r}\text { Chi-square } \\
(0 .\end{array}$ & $\begin{array}{l}\text { 4) }=17.97 \\
9)\end{array}$ \\
\hline
\end{tabular}
$\ln \left(\frac{G V A}{E m p l}\right)_{i t}$

* $p$-value - test probability $(p \in[0,1])$.

Source: own calculations in the Gretl software. 
The FEM and REM results confirm the impact of technical infrastructure (investments) on productivity in manufacturing. They also point to the significant impact of R\&D expenditure on labour productivity. The Hausman test indicates that the REM has a higher statistical value. The results obtained for this model allow us to state that a $1 \%$ increase in current $\mathrm{R} \& \mathrm{D}$ expenditure may result in an average increase in productivity of $0.05 \%$. The expenditure incurred in the time period $t-1$ influences labour productivity to a similar extent.

The applied Arellano-Bond and Sargan-Hansen tests indicate the correctness of the instruments used in the dynamic model. The estimation of the autoregressive coefficient is statistically significant and positive. This indicates a fairly high degree of persistence of labour productivity. A $1 \%$ change in productivity in the previous period causes a change in its current level of approximately $0.7 \%$. The estimation of the parameter for the variable embodying R\&D expenditure obtained using the SGMM estimator is lower than in the static models, and non-significant for lagged research and development expenditure. This may result from taking into account the lag for the response variable that reflects the impact of past expenditure on research and development on the response variable.

In the next step, labour productivity models defined as the value of sold production in relation to employment in a given division of manufacturing were considered. The static and dynamic model of thus understood productivity takes the form of:

$$
\begin{gathered}
\ln \left(\frac{S P}{E m p l}\right)_{i t}=\alpha_{i}+\beta_{0}+\beta_{1} \ln \left(\frac{I n v O}{E m p l}\right)_{i t}+\beta_{2} \ln \left(\frac{R \& D}{E m p l}\right)_{i t}+\beta_{3} \ln \left(\frac{R \& D}{E m p l}\right)_{i, t-1}+\varepsilon_{i t}, \\
\ln \left(\frac{S P}{E m p l}\right)_{i t}=\alpha_{i}+\beta_{0}+\gamma \ln \left(\frac{S P}{E m p l}\right)_{i, t-1}+\beta_{1} \ln \left(\frac{I n v o}{E m p l}\right)_{i t}+ \\
\beta_{2} \ln \left(\frac{R \& D}{E m p l}\right)_{i t}+\beta_{3} \ln \left(\frac{R \& D}{E m p l}\right)_{i, t-1}+\varepsilon_{i t}
\end{gathered}
$$

$\ln \left(\frac{S P}{E m p l}\right)_{i t}$ denotes the natural logarithm of the value of sold production at constant prices from 2009 in PLN million per employee for the $i$-th manufacturing division in the time period $t$.

The results of the estimation of the above-presented models are shown in the table below.

In this case, the Hausman test indicates that the FEM has a higher statistical value. The results obtained for this model allow us to state that a $1 \%$ increase in current expenditure on $\mathrm{R} \& \mathrm{D}$ may cause an average increase in productivity of $0.03 \%$. The impact of expenditure incurred in the time period $t-1$ is also significant and positive. Its $1 \%$ increase results in an average productivity increase of $0.02 \%$. It should be emphasised that this impact is lower than for productivity defined as GVA per employee. 
Table 3. Results of the estimation of parameters of labour productivity models in manufacturing $\ln \left(\frac{S P}{E m p l}\right)_{i t}$

\begin{tabular}{|c|c|c|c|c|c|c|}
\hline \multirow{3}{*}{$\begin{array}{c}\text { Explanatory } \\
\text { variables and } \\
\text { selected statistics }\end{array}$} & \multicolumn{6}{|c|}{ Dependent variable $\ln \left(\frac{S P}{E m p l}\right)_{i t}$} \\
\hline & \multicolumn{2}{|c|}{ FEM } & \multicolumn{2}{|c|}{ REM } & \multicolumn{2}{|c|}{ SGMM } \\
\hline & $\begin{array}{l}\text { Parameter } \\
\text { estimation }\end{array}$ & $\begin{array}{c}t \\
(p \text {-value })\end{array}$ & $\begin{array}{l}\text { Parameter } \\
\text { estimation }\end{array}$ & $\begin{array}{c}t \\
(p \text {-value })\end{array}$ & $\begin{array}{l}\text { Parameter } \\
\text { estimation }\end{array}$ & $\begin{array}{c}t \\
(p \text {-value })\end{array}$ \\
\hline $\ln \left(\frac{S P}{E m p l}\right)_{i, t-1}$ & - & & & & 0.610 & $\begin{array}{l}10.500 \\
(0.000)\end{array}$ \\
\hline $\ln \left(\frac{\operatorname{InvO}}{E m p l}\right)_{i t}$ & 0.269 & $\begin{array}{r}5.654 \\
(0.000)\end{array}$ & 0.284 & $\begin{array}{r}8.898 \\
(0.000)\end{array}$ & 0.178 & $\begin{array}{r}6.442 \\
(0.000)\end{array}$ \\
\hline $\ln \left(\frac{R \& D}{E m p l}\right)_{i t}$ & 0.035 & $\begin{array}{r}3.675 \\
(0.001)\end{array}$ & 0.0363 & $\begin{array}{r}2.975 \\
(0.002)\end{array}$ & 0.017 & $\begin{array}{r}2.961 \\
(0.0031)\end{array}$ \\
\hline $\ln \left(\frac{R \& D}{E m p l}\right)_{i, t-1}$ & 0.027 & $\begin{array}{r}2.940 \\
(0.008)\end{array}$ & 0.028 & $\begin{array}{r}2.198 \\
(0.027)\end{array}$ & 0.016 & $\begin{array}{r}3.211 \\
(0.001)\end{array}$ \\
\hline Constant & 5.191 & $\begin{array}{r}37.35 \\
(0.000)\end{array}$ & 5.148 & $\begin{array}{r}48.20 \\
(0.000)\end{array}$ & 1.825 & $\begin{array}{r}6.688 \\
(0.000)\end{array}$ \\
\hline$R$-squared & 0.97 & & & & & \\
\hline Within $R$-squared & 0.58 & & & & & \\
\hline $\begin{array}{l}\text { Assessment of the } \\
\text { significance of } \\
\text { individual effects } \\
\text { (value of test } \\
\text { statistics) }\end{array}$ & $\begin{array}{r}F=4 \varsigma \\
p=(0\end{array}$ & $\begin{array}{l}.02 \\
000)\end{array}$ & $\begin{array}{c}L M=38 \\
p=(0.0\end{array}$ & & & \\
\hline Hausman test & & & $\begin{array}{r}\text { Chi-square }(3 \\
p=(0.1\end{array}$ & $\begin{array}{l}=8.734 \\
33)\end{array}$ & & \\
\hline $\begin{array}{l}\text { Arellano-Bond } \\
\text { test (AR2) }\end{array}$ & & & & & $\begin{aligned} z=1 \\
(0.5\end{aligned}$ & $\begin{array}{l}552 \\
30)\end{array}$ \\
\hline $\begin{array}{l}\text { Sargan-Hansen } \\
\text { test }\end{array}$ & & & & & $\begin{array}{r}\text { Chi-squ } \\
14 . \\
(0.9\end{array}$ & $\begin{array}{l}\operatorname{re}(34)= \\
87 \\
82)\end{array}$ \\
\hline
\end{tabular}

* $p$-value - test probability $(p \in[0,1])$.

Source: own calculations in the Gretl software.

The applied Arellano-Bond and Sargan-Hansen tests indicate the correctness of the instruments used in the dynamic model. The estimation of the autoregressive coefficient is statistically significant and positive. The degree of persistence of the thus defined labour productivity is quite high. A change of $1 \%$ in productivity in the previous period causes a change in its current level of approximately $0.7 \%$. The estimation of the parameter for the variable embodying $R \& D$ expenditure obtained using the SGMM estimator is lower than in the static models. 


\section{Conclusions}

The economic crisis caused by speculation in the financial markets has forced a return to industry, which for many years was effectively pushed to the margins of the economy. The importance of industry is primarily due to the functions it plays in generating economic growth and employment.

The strength of the Polish economy stems from the fact that it has a quite optimal share of industry in GDP of approximately $23 \%$. This value is close to the result to be achieved by the EU in 2020. However, the issue of innovativeness, and thus the competitiveness of manufacturing, looks much worse in Poland. Under the conditions of globalisation of the economy, where ever-growing competition is constantly present, efficiency can be a way to consolidate or build a competitive advantage of manufacturing enterprises in the market. It is closely related to, among others, labour productivity. According to M. Porter, the impact of innovative activities of manufacturing divisions on their competitiveness is reflected in changes in labour and capital productivity. The reasons for the considerable diversity in the level of innovativeness of manufacturing divisions can be found in unequal outlays on innovative activity, including primarily R\&D activity.

The results of the conducted research indicate that internal $R \& D$ expenditure incurred by manufacturing enterprises has a significant impact on increasing labour productivity, regardless of the method of defining it. The impact of $R \& D$ expenditure that is the subject of the research, expressed in the estimation of the model parameter, is slightly higher in the case of labour productivity understood as gross added value per employee. However, with regard to technical infrastructure, expenditure related to research and development constitutes a secondary factor in changes occurring in the Polish manufacturing industry. The results of the dynamic panel models indicate a high degree of persistence in time of variously defined labour productivity, which means that its rapid changes in the short term can be difficult.

\section{Bibliography}

Aghion P., Bloom N., Blundell R., Griffith R., Howitt P., 2005, Competition and innovation: An inverted-U relationship, Oxford Journals, Quarterly Journal of Economics, vol. 120, no. (2), pp. 701-728.

Anderson T.W., Hsiao C., 1981, Estimation of dynamic models with error components, Journal of the American Statistical Association, vol. 76, pp. 598-606.

Arellano M., Bond S., 1991, Some tests of specification for panel data: Monte Carlo evidence and an application to employment equations, Review of Economic Studies, vol. 58, pp. 277-297.

Baltagi B.H., 2003, Econometric Analysis of Panel Data, Wiley \& Sons, Chichester.

Blundell R., Bond S., 1998, Initial conditions and moment restrictions in dynamic panel data models, Journal of Econometrics, vol. 87(1), pp. 115-143. 
Castellani D., Piva M., Schubert T., Vivarelli M., 2016, The Productivity Impact of R\&D Investment: A Comparison Between the EU and the US, Discussion Paper No. 9937.

Dańska-Borsiak B., 2011, Panelowe modele dynamiczne, Wydawnictwo Uniwersytetu Łódzkiego, Łódź.

European Commission, 2014, For a European Industrial Renaissance, Communication from the Commission to the European Parliament, the Council, the European Economic and Social Committee and the Committee of the Regions, $\operatorname{COM}(2014) 14$ final.

EUROSTAT, 2019a, Intra-EU Trade in Goods - Recent Trends, Statistics explained.

EUROSTAT, 2019b, First estimates of Research \&Development expenditure, News Release, 5/2019.

Freeman R., 2008, Labour Productivity Indicators. Comparison of Two OECD Databases Productivity Differentials \& The Balassa-Samuelson Effect, OECD Statistics Directorate, Division Of Structural Economic Statistics.

GUS, 2017, Rocznik Statystyczny Handlu Zagranicznego 2017, Warszawa.

GUS, 2018, Rocznik Statystyczny Przemysłu 2018, Warszawa.

Hsiao C., 2003, Analysis of Panel Data, 2nd ed. Cambridge, Cambridge University Press.

European Commission, 2010a, EUROPE 2020 A Strategy for Smart, Sustainable and Inclusive Growth, Communication from the Commission, $\operatorname{COM(2010)~} 2020$ final, Brussels, 3.3.2010 https://eur-lex.europa.eu/legal-content/EN/TXT/PDF/?uri=CELEX:52010DC2020\&from=EN.

European Commission, 2010b, An Integrated Industrial Policy for the Globalisation Era Putting Competitiveness and Sustainability at Centre Stage, Communication from the Commission to the European Parliament, the Council, the European Economic and Social Committee and the Committee of the Regions, $\operatorname{COM}(2010) 614$ final, Brussels, 28.10.2010, https://eurlex.europa.eu/LexUriServ/LexUriServ.do?uri=COM:2010:0614:FIN:EN:PDF.

European Commission, 2012, A Stronger European Industry for Growth and Economic Recovery, Industrial Policy Communication Update, Communication from the Commission to the European Parliament, the Council, the European Economic and Social Committee and the Committee of the Regions, COM (2012) 582 final, https://eur-lex.europa.eu/LexUriServ/LexUriServ.do?uri= COM:2012:0582:FIN:EN:PDF.

Lokshin B., Belderbos R.A., Carree M.A., 2008, The productivity effects of internal and external $R \& D$ : Evidence from a dynamic panel data model, Oxford Bulletin of Economics and Statistics, vol. 70(3), pp. 399-413, https://doi.org/10.1111/j.1468-0084.2008.00503.x.

Maddala G.S., 2006, Ekonometria, PWN, Warszawa.

Porter M.E., 1990, The Competitive Advantage of Nations, The Free Press, New York.

Porter M.E., 2001, Porter o konkurencji, PWE, Warszawa.

Raymond W., Mairesse J., Mohnen P., Palm F., 2013, Dynamic Models of R\&D, Innovation and Productivity: Panel Data Evidence for Dutch and French Manufacturing, National Bureau of Economic Research, Working Paper 1907, http://www.nber.org/papers/w19074.

Skrzypek E., 2012, Efektywność ekonomiczna jako ważny czynnik sukcesu organizacji, Prace Naukowe Uniwersytetu Ekonomicznego we Wrocławiu, nr 262.

Ślusarczyk B., 2016, Wspieranie konkurencyjności polskiego przemyslu w świetle zatożeń nowej polityki przemysłowej, Zeszyty Naukowe Politechniki Częstochowskiej Zarządzanie, nr 22(2016).

Świeczewska I., 2007, Łączna produktywność czynników produkcji. Ucieleśniony kapitał wiedzy, [in:] W. Welfe (ed.), Gospodarka oparta na wiedzy, Polskie Wydawnictwo Ekonomiczne, Warszawa.

Welfe W. (ed.), 2001, Ekonometryczny model wzrostu gospodarczego, Wydawnictwo Uniwersytetu Łódzkiego, Łódź.

Vieira E., Vazquez-Rozas E., Neira I., 2008, The innovation factor: An econometric model of productivity in European regions, Regional and Sector Economic Studies, vol. 8-1, pp. 59-70. 


\section{WPLYW NAKŁADÓW NA DZIALALNOŚĆ BADAWCZO-ROZWOJOWĄ NA WYDAJNOŚĆ W PRZEMYŚLE PRZETWÓRCZYM W POLSCE}

Streszczenie: W dokumentach strategicznych UE, w tym w Strategii Europa 2020, podkreśla się priorytetowe znaczenie przemysłu dla wzrostu gospodarek UE. Celem prezentowanego badania jest pomiar i ocena wpływu nakładów na działalność badawczą i rozwojową $(\mathrm{B}+\mathrm{R})$ na konkurencyjność działów przetwórstwa przemysłowego w Polsce. Za miernik konkurencyjności przyjęto wydajność pracy wyrażoną jako (1) iloraz wartości dodanej brutto i wielkości zatrudnienia oraz (2) iloraz produkcji sprzedanej $\mathrm{i}$ wielkości zatrudnienia $\mathrm{w}$ analizowanych działach przetwórstwa przemysłowego. Część empiryczna artykułu bazuje na danych publikowanych przez Główny Urząd Statystyczny. Analiza obejmuje lata 2009-2017 i stanowi przyczynek do określenia roli i znaczenia działalności badawczo-rozwojowej i innowacyjnej w kształtowaniu przewag konkurencyjnych przedsiębiorstw przetwórstwa przemysłowego. Uzyskane wyniki dla modeli panelowych potwierdzają, że nakłady związane $\mathrm{z}$ działalnością badawczo-rozwojową stanowią drugoplanowy czynnik zmian w polskim przemyśle przetwórczym.

Słowa kluczowe: nakłady na $\mathrm{B}+\mathrm{R}$, konkurencyjność, przetwórstwo przemysłowe, statyczne modele panelowe, dynamiczne modele panelowe. 